\title{
COOPERATION MANAGEMENT MODEL: A CASE STUDY AT THE FACULTY OF ECONOMICS UNIVERSITAS NEGERI MEDAN
}

\author{
Hilma Harmen ${ }^{1}$, ORCID: 0000-0003-2178-2489, \\ Muhammad Bukhori Dalimunthe ${ }^{1 *}$, ORCID: 0000-0002-2422-5568, \\ Wildansyah Lubis ${ }^{1}$, ORCID: 0000-0003-4949-7866, \\ Lokot Muda Harahap ${ }^{1}$, ORCID: 0000-0003-2795-5707, \\ Raudah Zaimah Dalimunthe², ORCID: 0000-0001-7463-3802 \\ ${ }^{1}$ Universitas Negeri Medan, Jalan Willem Iskandar Pasar V, Medan, Sumatera Utara, Indonesia \\ ${ }^{2}$ Universitas Sultan Ageng Tirtayasa, Jalan Raya Palka Km 3 Sindang Sari, Serang, Banten, Indonesia \\ ${ }^{*}$ Corresponding author: Muhammad Bukhori Dalimunthe, daliori86@unimed.ac.id
}

\begin{abstract}
The purpose of this paper is to explore the collaboration that has been implemented in the curriculum as a cooperation management model to support campus performance indicators. Cooperation management uses the management functions introduced by Robbins et al., namely planning, organizing, operating, coordinating and evaluating. The case studies used in this research involve all study programs $(N=9)$ at the Faculty of Economics Universitas Negeri Medan, Indonesia. The data were collected using a questionnaire consisting of items focused on a differential semantic scale and qualitative responses to all items submitted at the time of the interview. This paper also reveals the dominant functions of cooperation management performed in the study program, namely: organization (8.00), planning (7.87), coordination (7.75), action (7.56), respectively evaluation (6.96). The function of the actuating and evaluation components is a severe concern for campus leaders. Flexibility and commitment to fund management support is essential for existing collaborations and plans for cooperation on strategic objectives. The implications of the study's findings - the model of industrial cooperation to strengthen collaboration between the two sides will serve for the future.
\end{abstract}

Keywords: planning, organizing, actuating, coordinating, evaluating, study program-industry cooperation.

Rezumat. Scopul acestei lucrări este de a explora colaborarea care a fost implementată în programul de studii ca model de management al cooperării pentru a susține indicatorii de performanță ai campusului. Managementul cooperării folosește funcțiile de management introduse de Robbins și colab., și anume planificarea, organizarea, acționarea, coordonarea și evaluarea. Studiile de caz utilizate în această cercetare implică toate programele de studiu $(\mathrm{N}=9)$ la Facultatea de Economie Universitas Negeri Medan, Indonezia. Datele au fost colectate folosind un chestionar format din itemi axat pe o scară semantică diferențială și răspunsuri calitative la toți itemii depusi la momentul interviului. Această lucrare relevă, de 
asemenea, funcțiile dominante de management al cooperării îndeplinite în programul de studii și anume: organizare $(8,00)$, planificare $(7,87)$, coordonare $(7,75)$, acționare $(7,56)$, respectiv evaluare $(6,96)$. Funcția componentelor de acționare și evaluare este o preocupare severă pentru liderii din campus. Flexibilitatea și angajamentul de a finanța sprijinul din partea conducerii este esential pentru colaborările și planurile existente de cooperare pe obiective strategice. Implicațiile constatărilor studiului - modelul de cooperare industrială pentru consolidarea colaborării dintre cele două părți vor servi pentru viitor.

Cuvinte cheie: planificare, organizare, acționare, coordonare, evaluare, program de studiicooperare industrie.

\section{Introduction}

The presence of universities provides a domino effect that contributes to the economy and social life through university-industry cooperation on the application or transfer of knowledge and technology [1]. The increasingly competitive economic competition gives rise to new products that meet consumer needs. The product is obtained from knowledge and technology transfer from universities to industry [2]. So college is so urgent for the development of the company. However, the application of higher education products still faces many challenges, especially the sustainability and commercialization of good products in the market. This is one of the reasons for the urgency of the transformation of higher education that strengthens cooperation with industry.

Higher education in Indonesia intensely establishes strong cooperation between universities and industry. Many research and development activities have been carried out to support productivity between the two parties [3]. Education policy in Indonesia is transforming to measure universities' performance, determining the classification or ranking of universities through the key performance indicators (Indikator Kinerja Utama - IKU).

Since 2020, the IKU has been issued through a decree of the Minister of Education and Culture, which is a performance measure for universities to create adaptive and output-based universities that are more concrete. There are eight college IKU, namely: 1) alumni get good jobs; 2) students get an off-campus learning experience; 3 ) lecturers are active outside the campus; 4) practitioners teach on campus; 5$)$ the work or products of lecturers are used by the community or get international recognition; 6) study programs in collaboration with world-class partners; 7) collaborative and participatory classes; and 8) international standard study programs [4]. To that achieve the target of IKU, strong cooperation with the industry and the best universities are needed. Cooperation is the main foundation to reach IKU, which in turn has an impact on university rankings.

There has been a significant transformation of higher education in Indonesia into a world-class campus. The IKU assessment leads to creating a world-class campus that tends to be oriented towards classroom learning activities centered on student and lecturer activities. A learner-centered, action-oriented learning approach, building networks among students from various campuses is an effective way to improve generations [5]. In addition, these learning activities will create an integrated interaction between the higher education curriculum and industry.

Industrial partners who will collaborate with study programs must consider the core business's suitability with the study program's needs, especially the Merdeka Belajar curriculum. So that the study program coordinators develop the Merdeka Belajar curriculum structure that is relevant to industry needs [6]. Ran et al., [7] explained several stages in 
partner selection in cooperating, namely 1) collecting data and pre-processing data, 2) identify the topic of cooperation, 3) determine partner clusters, and 4) partner exploration. They further explained that partners' availability of data and patents is the primary information that determines which partners will cooperate with universities. Therefore, the study program can use these stages as a filter that will determine potential partners and mutualism by improving the performance of the study program.

Many scholars have revealed university-industry cooperation [1 - 3], [11, 12], by involving various factors or constructs that influence the cooperation. However, this paper offers something new to explore the cooperation of study programs-industry, which is more fundamental than the organizational structure of a university by involving management functions. Therefore, the purpose of this paper is to design a study program-industrial cooperation management model using the management functions developed by Robbins et al., [12] namely planning, organizing, actuating, coordinating, and evaluating.

\section{Method}

This study uses a qualitative approach by using the case study method [13]. Collecting data using a questionnaire consisting of 1 ) an assessment of the question items using a differential semantic scale, and 2) qualitative responses to all items that respondents will explore during interviews [10]. The interview instrument adopted Mahmudah [11] combined with the management functions proposed by Robbins et al., [12] namely planning, organizing, actuating, coordinating, and evaluating. The respondents were all heads of study programs $(\mathrm{N}=9)$ at the Faculty of Economics Universitas Negeri Medan, Indonesia. The data analysis technique Miles and Huberman was used through data reduction, data presentation, and concluding stages [13].

\section{Results and Discussion}

Based on the data collected, the respondent profile is obtained, which is described as follows.

Table 1

\begin{tabular}{ll}
\multicolumn{2}{c}{ Respondent profile } \\
\hline Profile & $\mathrm{N}$ \\
\hline Study program & 9 \\
Education & 4 \\
Non education & 5 \\
\hline Gender & 9 \\
Male & 6 \\
Female & 3 \\
\hline Education level & 9 \\
Master & 6 \\
Doctor & 3 \\
\hline
\end{tabular}

The Faculty of Economics Universitas Negeri Medan consists of nine study programs divided into two types, namely educational $(\mathrm{N}=4)$ and non-educational $(\mathrm{N}=5)$. The educational study program consists of accounting education, education of office administration, business education, and economic education. Meanwhile, non-educational study programs consist of accounting, management, economics, digital business, and entrepreneurship. The respondents $(\mathrm{N}=9)$ were the coordinator of the study program, which was dominated by male 
$(\mathrm{N}=6)$, while the rest were female $(\mathrm{N}=3)$. Furthermore, the responses were dominated by master's education background $(\mathrm{N}=3)$, while the rest were doctoral $(\mathrm{N}=6)$. The reduced data and the presentation of the findings from the data collected in the results and discussion section are described comprehensively in the next section. Then proceed, drawing conclusions expressed in the last section.

The respondents gave an assessment (using a differential semantic scale) on a scale of 1-10 on each question item used to delve information through interviews. Therefore, the assessment of the cooperation management function that has been carried out confirms the primary data obtained from interviews. The data collected is then reduced to Table 2, which provides preliminary information that reveals the dominant management functions performed in the study program-industry cooperation.

Table 2

\section{Data analysis related to cooperation management function}

Management Function Mean

1. Planning

7.87

1.1. Accommodate a meeting for the preparation of cooperation with the leadership.

8.44

1.2. Provide the preparation of a cooperation plan.

1.3. Performing cooperation needs analysis.

1.4. Provide the preparation of the cooperation program.

8.22

1.5. Provide the preparation of the cooperation program.

1.6. Selecting and determine in collaboration with industry.

7.89

1.7. Provide the preparation of a Memorandum of Understanding.

6.56

2. Organizing

8.00

2.1. Division of work units according to need.

8.11

2.2. Grouping of work units that describe the division of tasks.

2.3. There are details of the work to be done.

3. Actuating

3.1. Synchronizing curriculum with practitioners from industry.

3.2. Establishing standards for the implementation of cooperation with industry.

7.00

3.3. Assessment of the implementation of the cooperation program.

3.4. We are cooperating in the form of internships or field practice.

3.5. Maintain continuous communication with the industry.

3.6. Involving practitioners from industry in academic activities.

4. Coordination

4.1. Make adjustments to togetherness and balance between parties.

4.2. Prevent conflicts of interest in the implementation of cooperation..

4.3. Creating efficiency and effectiveness in cooperating.

4.4. Clarity of division of tasks between study programs-industry.

7.11

5. Evaluating

5.1. Manage internal evaluations related to the cooperation that has bee implemented.

7.00

5.2. Prepare a report on the implementation of the study program-industry cooperation. $\quad 6.44$

5.3. Evaluation from faculty or the university related to the implementation of

7.44 cooperation.

Actual Mean

7.63

Information obtained from Table 1 reveals that the most dominant management functions are initiated by organizing (8.00), planning (7.87), coordinating (7.75), actuating (7.56), and evaluating (6.96), respectively. In contrast, the average value is 7.63. It was further 
disclosed that the management functions above the average value are organizing, planning, and coordinating, while the actuating and evaluating functions are still below the average. Furthermore, the data that has been reduced is then presented in detail on the tasks of cooperation management based on information during interviews with respondents.

\section{1) Planning}

At this early stage, the study program coordinators explained that the cooperation plan was prepared based on the need to support learning effectiveness. Cooperation programs are designed jointly by involving coordinators, faculty leaders, and industry. In conducting cooperation, it is necessary to select specific partners with the expertise of the alumni. So that alumni can be absorbed to work in the industry.

Respondent 1 \& Respondent 2: a cooperation program was prepared jointly involving stakeholders from faculty and industry.

Respondent 6 \& Respondent 9: the topic of cooperation must be relevant and urgent with shared needs. So it takes a team consisting of elements of the two parties to formulate the studyindustry program collaboration.

Respondent 7 \& Respondent 9: the selection of partners must be specific by taking into description the needs of the study program. For educational study programs, cooperation can be done with schools or educational institutions. Meanwhile, non-educational study programs can collaborate with companies or institutions that are in line with alumni expertise.

Several records from the respondents found that the planning aspect has been effective in supporting study programs-industry cooperation. This finding is also supported by the respondents' perception of the planning aspect (7.87), above the average value.

\section{2) Organizing}

This stage is the most dominant aspect in the study program-industry cooperation management function, with the highest average value (8.00) compared to other management functions.

The interview results found who had carried out the division of labor, a grouping of work units, and explanation of work details well in the study program-industry cooperation. Some of the information obtained from the respondents is described as follows.

Respondent 1: each work unit has carried out its duties according to its function.

Respondent 2: the division of tasks related to cooperation with industry has been described in detail based on the needs of the study program.

Respondent 6: there is a delegation of tasks between the leader and the coordinator.

\section{3) Actuating}

The actuating function does not work optimally in the management of the study program-industry cooperation. Who found that the average value of the actuating aspect (7.56) was below the actual average. Some of the urgent information obtained from the interview is described as follows.

Respondent 1 \& Respondent 7: currently, there have been several cooperation, but the implementation of the cooperation has not been carried out.

Respondent 4 \& Respondent 9: In academic activities, partners have been involved in providing lectures, e.g., public lecture programs.

Several regular activities from faculty and the university have been carried out well. However, at the study program level, the actuating of cooperation has not been optimal. It 
takes commitment and financial support to realize cooperation programs in study programs that will impact campus performance.

\section{4) Coordinating}

The coordinating function in the management of study program-industry cooperation has been running effectively. The study program coordinators adapt and support the benefits received by both parties. A clear division of tasks and responsibilities has been drawn up between the two parties in planning and actuating the cooperation. Likewise, in anticipating conflicts of interest on the actuating of cooperation that has been prevented when determining partners. Some of the crucial information obtained during the interview is described as follows.

Respondent 2, Respondent 6, Respondent 9: harmonization and adjustment of the benefits of cooperation between study programs-industry carried out every year.

Respondents 1 \& Respondent 7: conflicts of interest are highly avoided and presented at the determining stage.

Respondent 1 \& Respondent 9: the efficiency and effectiveness of cooperation continue to be carried out due to budget constraints. Cooperation is prioritized on partners who can support the performance of study programs at a more efficient cost.

\section{5) Evaluating}

The evaluation function has not been optimally carried out. This finding is reinforced by the mean value of the evaluation function (6.96), which is the lowest value and is below the actual mean. Evaluation is closely related to the actuating function. If the actuating function is not carried out optimally, the evaluation function is not effectively implemented. Likewise, the reporting of cooperation activities, which of course, will not be able to be compiled by the study program. Some of the urgent information obtained from the respondents is described as follows.

Respondent 1, Respondent 6, Respondent 7: there is no report on implementing cooperation with industry.

Respondent 1: no evaluation of the cooperation between faculty and the university has yet been carried out.

The interview information related to the cooperation management function carried out in the study program can visually describe the management model of the study programindustry cooperation.

The findings of this research complement the research that has been done related to the management of cooperation higher education with industry. The university can apply knowledge to industry to create innovations and new technologies through universityindustry collaboration [5]. Therefore, cooperation for both parties can increase effectiveness and efficiency in developing innovation for production and knowledge.

Briones et al., [8] describe the university collaboration management model's components that begin with phases, stages, inputs, and outputs. Their phase components are defined as sensitivity, diagnosis, and integration of strategies to achieve cooperative goals. A similar statement was also expressed by Ran et al., [7] that in cooperating with the industry, it is necessary to explore information on potential and inline partners to cooperate. Furthermore, cooperation fostered by both parties can stimulate motivation to conduct research and build interaction between research networks between institutions or countries [14]. 


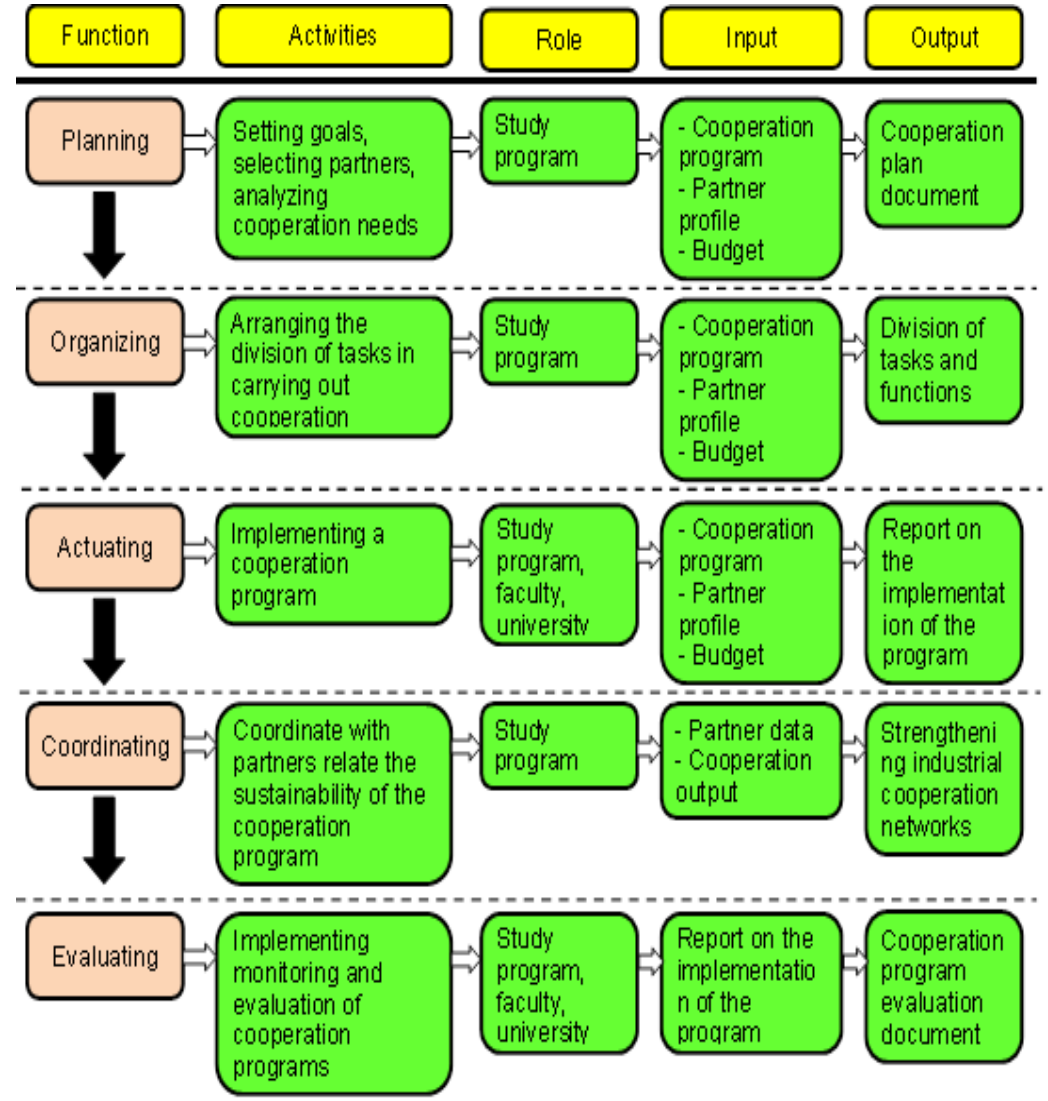

Figure 1. Management model of cooperation study programs-industry.

Early strategic steps must consider the benefits that both parties will feel. So that cooperation planning must be carefully prepared and look for suitable partners and support the achievement of the targets that have been set. The reputation of partners in the industry is a significant consideration for establishing university trust in collaborating [15]. The research findings show that the planning function performed by the study program plays an essential role in supporting the implementation of learning which in turn has an impact on the achievement of higher education IKU.

Likewise, for the organizing and coordinating functions that effectively support the management of study program-industry cooperation. The organizational structure in cooperating involves competent lecturers and staff to coordinate the division of tasks. Nevertheless, management functions in planning, organizing, and coordinating are still dominated by the role of study programs in cooperating. So the average value of these aspects is above the average.

However, in the actuating and evaluation functions, the cooperation involves stakeholders at the faculty and university levels, especially financial needs. Who found some of the information from the respondents to be a management construct for the study program-industry. First, the dependence of the study program is extreme on the faculty and university on these two aspects. Of course, this causes the study program to only carry out routine tasks without paying attention to cooperation with the industry. Furthermore, the leaders firmly commit to supporting the study program in cooperation with the industry [16]. Second, the flexibility of the study program is also needed because the topic of collaboration among study programs is very different. The flexibility of cooperation should be centered on study programs that support the university performance targets. Integrated cooperation between study programs and university as mutual support that needs each other to achieve 
the best ranking. Lastly, financial support from stakeholders on campus. Currently, the university is undergoing a financial management transition period, so it is necessary to adapt financial management from all units, including study programs.

\section{Conclusion}

The management model of the study program-industry cooperation has been formed by considering the management functions, including planning, organizing, actuating, coordinating, and evaluating. Several management functions have been running effectively to support cooperation. However, the planning and evaluation aspects still require serious attention and commitment from university leaders. Cooperation is a fundamental and urgent part of keeping university ranking performance. Thus, the version of the study program becomes the main focus of supporting programs that the university has determined to achieve the best ranking. Independence, commitment, flexibility, and financial support are challenges study programs face in knitting cooperation with industry. This finding has implications for management functions that need to be maintained and improved to support university performance. Corrective actions on weak aspects can inspire other researchers to take initial steps and anticipate technological developments in the industry in developing a cooperation management model for the study programs-industry that are more adaptive to technological developments.

Acknowledgments. The authors researched with sponsorship from Universitas Negeri Medan through a fundamental research grant scheme in 2021. So we are grateful for the research funding that has been provided.

\section{References}

1. Bektaş Ç. and Tayauova G. A Model Suggestion for Improving the Efficiency of Higher Education: UniversityIndustry Cooperation. In: Procedia - Soc. Behav. Sci., vol. 116, pp. 2270-2274, 2014, doi: https://doi.org/10.1016/j.sbspro.2014.01.558.

2. Yalçıntaş M., Kaya C. Ç., and Kaya B. University-Industry Cooperation Interfaces in Turkey from Academicians' Perspective. In: Procedia - Soc. Behav. Sci., vol. 195, pp. 62-71, 2015, doi: https://doi.org/10.1016/j.sbspro.2015.06.330.

3. Othman R., and Omar A. F. University and industry collaboration: towards a successful and sustainable partnership. In: Procedia - Soc. Behav. Sci., vol. 31, pp. 575-579, 2012, doi: https://doi.org/10.1016/j.sbspro.2011.12.106.

4. Menteri Pendidikan dan Kebudayaan. Indikator Kinerja Utama Perguruan Tinggi Negeri dan Lembaga Layanan Pendidikan Tinggi di Lingkungan Kementerian Pendidikan dan Kebudayaan. In: Jakarta, Indonesia: Biro Hukum Kemendikbud, 2020, p. 30.

5. Fokdal J., Čolić R., and Milovanović Rodić D. Integrating sustainability in higher planning education through international cooperation. In: Int. J. Sustain. High. Educ., vol. 21, no. 1, pp. 1-17, Jan. 2020, doi: 10.1108/JJSHE01-2019-0045.

6. Maipita I., Dalimunthe M. B., and Sagala G. H. The Development Structure of the Merdeka Belajar Curriculum in the Industrial Revolution Era. 2021, pp. 145-151, doi: https://doi.org/10.2991/aebmr.k.210220.026.

7. Ran C., Song K., and Yang L. An improved solution for partner selection of industry-university cooperation. In: Technol. Anal. Strateg. Manag., vol. 32, no. 12, pp. 1478-1493, Dec. 2020, doi: 10.1080/09537325.2020.1786044.

8. Briones V. F. V., Entenza N. P. Gámez M. R. and Cedeño M. R. Management model for university cooperation at Universidad Técnica de Manabí, Ecuador. In: Int. Res. J. Manag. IT Soc. Sci., vol. 3, no. 9, pp. 1-8, Sep. 2016, [Online]. Available: https://sloap.org/journals/index.php/irjmis/article/view/387.

9. Creswell J. W. Research design: Quantitative, qualitative and mixed methods. In: 4th ed. United States of America: Thousand Oaks, CA: Sage, 2014.

10. Mardapi D. Pengukuran, Penilaian, dan Evaluasi Pendidikan (Edisi 2). In: Yogyakarta: Parama, 2017.

11. Mahmudah F. Model Manajemen Kerjasama SMK dengan Dunia Kerja yang Saling Menguntungkan. Dissertation. Doctor of Education Management: Universitas Negeri Yogyakarta, 2019.

12. Robbins S. P. Coulter M. A. and. De Cenzo D. A. Fundamentals of Management. In: $11^{\text {th }}$ Edition, $11^{\text {th }}$ ed London: Pearson, 2020. 
13. Huberman M., and Miles M. B. The qualitative researcher's companion. Los Angeles: Sage, 2002.

14. Franco M., and Haase H. University-industry cooperation: Researchers' motivations and interaction channels. In: J. Eng. Technol. Manag., vol. 36, pp. 41-51, 2015, doi: https://doi.org/10.1016/j.jengtecman.2015.05.002.

15. Hemmert M., Bstieler L., and Okamuro H. Bridging the cultural divide: Trust formation in university-industry research collaborations in the US, Japan, and South Korea. In: Technovation, vol. 34, no. 10, pp. 605-616, 2014, doi: https://doi.org/10.1016/j.technovation.2014.04.006.

16. Nomakuchi T., and Takahashi M. A Study about Project Management for Industry-University Cooperation Dilemma. In: Procedia Comput. Sci., vol. 64, pp. 47-54, 2015, doi: https://doi.org/10.1016/j.procs.2015.08.462. 